\title{
Comparative physico-chemical and faunal studies of two thermal springbrooks near Sidi Harazem (Morocco)
}

\author{
I. Berrady 1 \\ K. Essafi ${ }^{1}$ \\ J. Mathieu 2,3
}

Keywords : groundwater, Moroccan hot springs, interstitial communities.

The origin of the water of the two Sidi Harazem springs (Morocco), was found to be different. Environmental parameters made it possible to recognise three types of water : one issuing from a "cool spring", with lowest temperature (mean : $26.7^{\circ} \mathrm{C}$ ), conductivity and chloride concentration ; one issuing from the "hot spring" (mean : $31.7^{\circ} \mathrm{C}$ ) with the highest temperature and high conductivity; and the one of the oued itself with into which both springs flow. This oued had the highest values of $\mathrm{pH}$, conductivity, chlorides, and calcium. The interstitial fauna collected by means of artificial substrates was composed of both epigean and stygobite species. Only the "cool spring" included stygobite species, the number of which generally decreased with depth.

\section{Etudes physico-chimique et faunistique comparatives de deux sources thermales près de Sidi Harazem (Maroc)}

Mots-clés : eau souterraine, sources chaudes marocaines, communautés interstitielles.

Les eaux de deux sources situées à Sidi Harazem (Maroc), ont une origine différente. Les paramètres physico-chimiques ont permis de séparer trois types d'eau : l'une, issue de la "source froide" avec les valeurs les plus basses de température $\left(26.7^{\circ} \mathrm{C}\right.$ en moyenne), de conductivité et de teneur en chlorures; l'autre, issue de la "source chaude" ( $31.7^{\circ} \mathrm{C}$ en moyenne), avec une température et une conductivité élevées ; la troisième, celle de l'oued dans lequel se jettent les deux sources, montre des valeurs élevées de $\mathrm{pH}$, de conductivité, de chlorures et de calcium. La faune interstitielle, récoltée à l'aide de substrats artificiels, est composée à la fois d'espèces épigées et hypogées. Seule la "source froide" renferme des espèces stygobies dont les effectifs diminuent avec la profondeur.

\section{Introduction}

The studies on the Moroccan stygobite fauna began in 1978-1979 with the inventory of a first list of species collected from 59 wells distributed all over the Morocco (Magniez 1978, Pesce et al. 1981). Later, these were completed by other scientists in the Marrakech area (Boutin \& Boulanouar 1984, Boutin \& Messouli 1988), in Goulmina, Tiznit, and Essaouira areas (Boutin \& Idbennacer 1984), Fès area (Essafi et al. 1998) and in Eastern Morocco (Essafi-Chergui 1990). These studies were carried out with the idea that the groundwater could be considered as the main resource for

1. Laboratoire d'Hydrobiologie et Ecologie Générale, Faculté des Sciences Dhar El Mehraz, Fès, Maroc.

2. Laboratoire d'Hydrobiologie et Ecologie Souterraines, Université Claude Bernard Lyon I, ESA CNRS 5023, 43 Bd du 11 novembre 1918, F-69622 Villeurbanne Cedex France.

3. Correspondant author: Tél : (33) 472431364 . Fax : (33) 472

4315 23. E-mail : mathieu@biomserv.univ-lyon1.fr drinking water and that a good knowledge of the environment could allow its management and its protection (Gibert 1992).

Water quality of surface water, which influences that of groundwater and the reverse (Valett et al. 1990), can be evaluated by the study of its chemical and physical parameters, but also from the information given by those organisms that are sensitive to the changes in their environment. The sensitivity of these organisms to different pollutants changes from one species to another (review Gibert et al. 1995). The pollution of the saturated zone of karstic areas by urban waste water might be indicated by low values in the number of stygobites compared to those of epigean species (Turquin \& Crague 1994, Malard et al. 1996a), and the enrichment of the groundwater by organic matter is demonstrated by a high density of aquatic invertebrates such as Oligochaeta, Ostracoda and Isopoda (Malard et al. 1996b, Plénet 1995, Plénet \& Gibert 1995, Plénet et al. 1996). 
Springs are a natural source of groundwater and their physical and chemical composition depends on the various strata with which the water has been in contact, but also on the various chemicals that percolate into the groundwater (Webb et al. 1998).

Recent studies on springs have been undertaken in Morocco, in the Fès area, in sites characterized by water flowing from karstic springs and supplying the alluvial plains of oueds. The aim of these studies was to show the interface effects of these zones, especially on the changes in physical and chemical parameters and on the quantity and quality of the interstitial fauna. In a US hot spring, Lamberti \& Resh (1983) showed that the thermal component of geothermal fluids had greater influence than the chemical component in determining benthic community features. Especially, a natural input of geothermal fluids which elevated both temperature and chemical levels doubled invertebrate density. In the same way, Glazier (1991) explained the benthic community structure of different springs (especially hot springs) by influence of water quality. The springs of Sidi Harazem were chosen here for their particular configuration. They are two springs, the water origins of which are different, one with a mean temperature of $26^{\circ} \mathrm{C}$, the other with about $31^{\circ} \mathrm{C}$. Their waters join about $70 \mathrm{~m}$ downstream from their outflow after having received some waste water from the oued (Fig. 2). So it was interesting to observe ecological parameters and interstitial fauna changes in such a situation.

\section{Material and methods}

\subsection{Study area}

The observations were carried out in an area located $12 \mathrm{~km}$ south-east of the city of Fès. The thermomineral springs of Sidi Harazem are well known for their therapeutic properties (Combe 1975).

The hydrogeological system is composed of about $50 \mathrm{~m}$ thick Lias limestone and dolomite (Ben Aabidate 1994) (Fig. 1). This limestone and dolomite is covered by Miocene sandstone and clay. The springs border a fault which is visible at Sidi Harazem. Five springs exist which are covered by a thick layer of travertin.
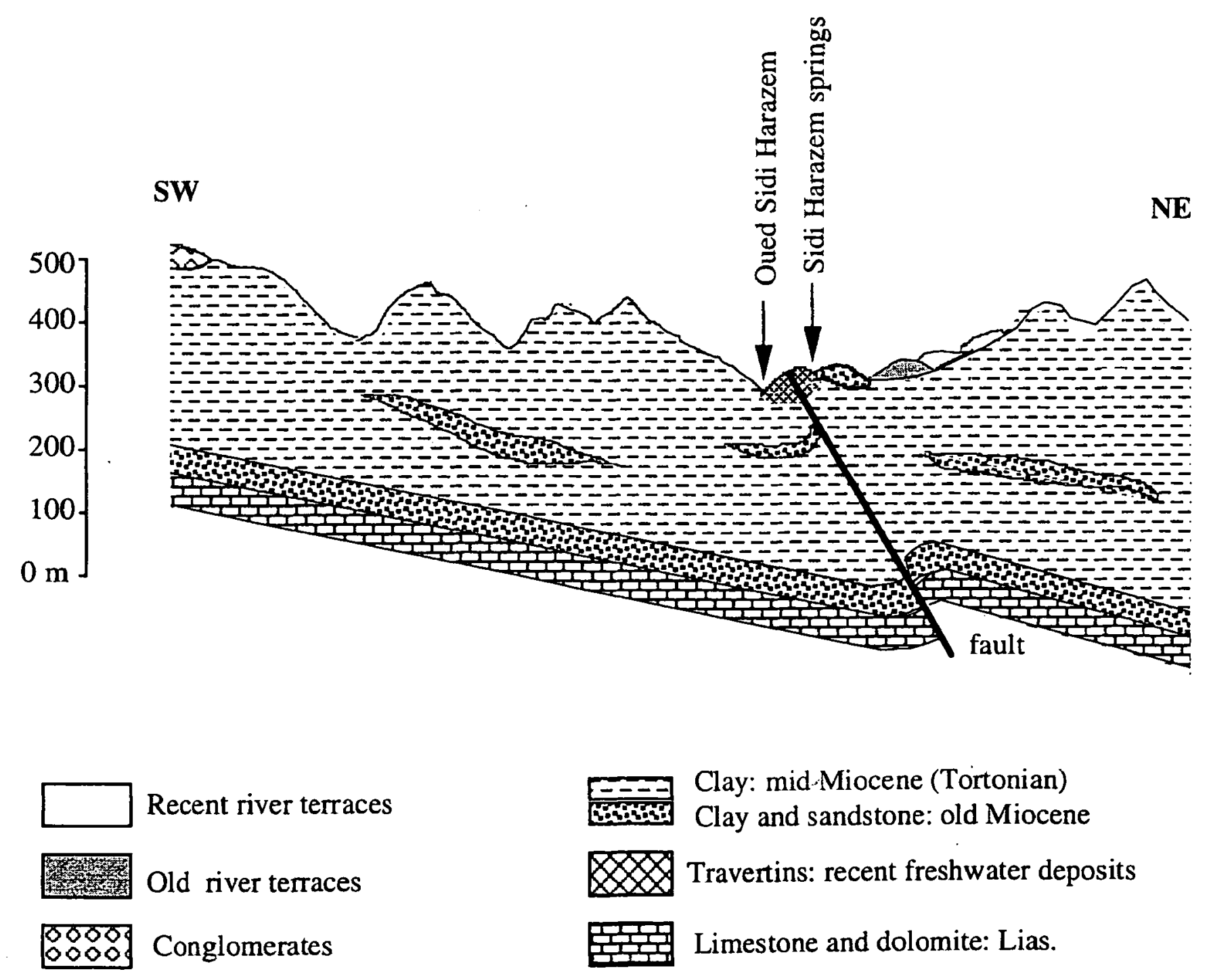

Fig. 1. Geological section through the Sidi Harazem springs (from Ben Abidate 1994).

Fig. 1. Coupe géologique au niveau des sources de Sidi Harazem (d'après Ben Abidate 1994). 
Two of them, and their springbrooks, have been selected for this study. The first, the "cool spring", is characterized by a temperature of about $27^{\circ} \mathrm{C}(25.6$ to $28^{\circ} \mathrm{C}$ ). A part of its water is used by the RADEFF Society to supply the Sidi Harazem area with drinking water. The second one, characterized by a temperature of about $31^{\circ} \mathrm{C}\left(28.6\right.$ to $\left.33^{\circ} \mathrm{C}\right)$, is used by the thermal spa, and the SOTHERMA Society for its marketing.

These springs are distant by about $150 \mathrm{~m}$. Eight stations chosen to place the artificial substrates (Fig. 2) : S1, S2 and S3 on the "cool stream" downstream from the "cool spring", $S 4$ in the stream polluted by the spa, S5 just after the confluence of this polluted stream with the "cool stream", S6 and S7 downstream from the "hot spring", and S8 downstream from the confluence of oued Sidi Harazem with the "hot stream".

\subsection{Sampling of fauna}

Artificial substrates allows to observe the changes of population components with depth and time in the sediment (Laville 1974, Khalaf \& Tachet 1977, Mathieu \& Essafi-Chergui 1990). Each artificial substrate used in this study, as described by Mathieu et al. (1987), consisted of a cylinder $10 \mathrm{~cm}$ in diameter and $50 \mathrm{~cm}$ long in which $8 \mathrm{~mm}$ holes had been drilled. Each cylinder was buried in the stream bed and contained five baskets one above the other, made of $6 \mathrm{~mm}$ metallic mesh (diameter : $10 \mathrm{~cm}$; height : $10 \mathrm{~cm}$ ) (Mathieu \& Essafi-Chergui 1990). Each basket was filled with the local sediment, but before filling them, this sediment was carefully cleaned and dried in the laboratory, and thus initially free of animals. This sediment was poorly sorted and mainly composed of angular gravel, bet-

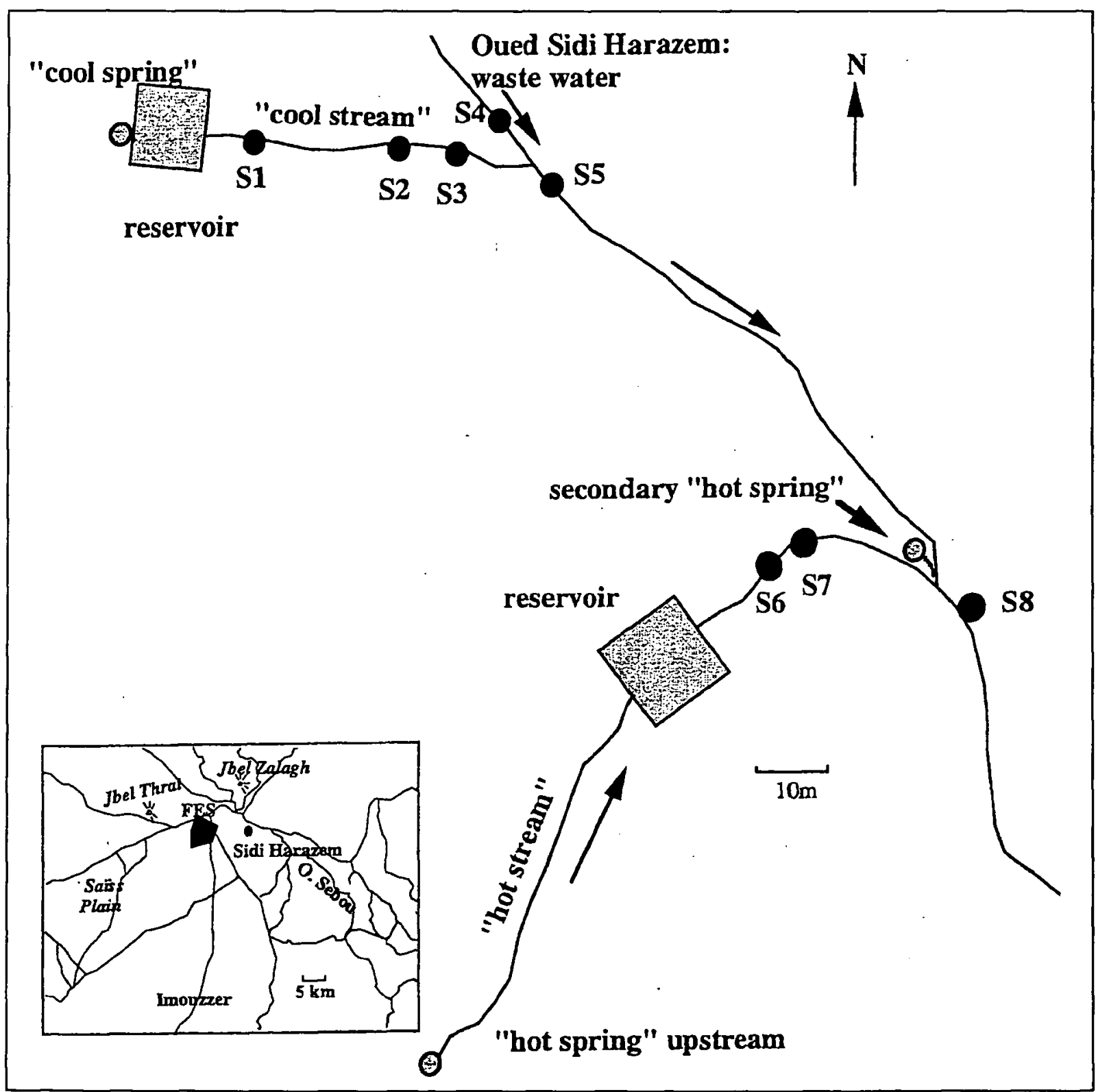

Fig. 2. Sketch map of the study area with the Sidi Harazem springs. S1 to S8 : stations where the artificial substrates were buried.

Fig. 2. Carte de la région d'étude avec les sources de Sidi Harazem. S1 à S8 : stations où les substrats artificiels ont été immergés. 
ween $4 \mathrm{~mm}$ and $40 \mathrm{~mm}$ diameter, and fine sand $(<1$ $\mathrm{mm}$ ) which plugged up the space between the gravel.

The artificial substrates were exposed for one month, the estimated duration needed to obtain the equilibrium between organic matter supply and fauna in the substrate.(Khalaf \& Tachet 1977, Mathieu \& Essafi-Chergui 1990, Mathieu et al. 1987). Each station was sampled approximately monthly and 13 collections occurred from 15 April 1998 to 9 May 1999.

In the laboratory, all the material from each basket was washed through a $160 \mu \mathrm{m}$ mesh sieve. After removal of most sand and gravel, the animals were picked from the residue and preserved in $4 \%$ formalin, and then, identified (the identification of Cladocera and insect larvae was difficult, mainly owing to the presence of early stages).

\subsection{Physical and chemical analysis of water}

The physical and chemical parameters of both surface water and ground water were measured. Water was taken in $500 \mathrm{ml}$ bottles, directly in the stream for surface water, at $50 \mathrm{~cm}$ in the artificial substrates for ground water, when the lowest basket was removed.

Temperature, $\mathrm{pH}$, conductivity and dissolved oxygen were measured in situ, the other chemical parameters in the laboratory. Temperature and conductivity were measured with a Bioblock LF 318 conducty-thermometer, $\mathrm{pH}$ with a Bioblock WTW $320 \mathrm{pH}$ meter, dissolved oxygen with a Bioblock OXI 320 IP66 oximeter. The other chemical parameters (total hardness, calcium, chloride ions, and also parameters indicating pollution, such as sulphate, orthophosphate and nitrate) were determined following methods described in

Table 1. Mean values, ranges and standard deviations of physical and chemical parameters of 8 stations of Sidi Harazem site, between 15/04/98 and 09/05/99. (I.W. : interstitial water ; S.W. : surface water).

Tableau 1. Valeurs moyennes, écarts et déviations standard des paramètres physiques et chimiques des 8 stations du site Sidi Harazem, entre le 15/4/98 et le 09/05/99 (I.W. : eau interstitielle ; S.W. : eau de surface).

\begin{tabular}{|c|c|c|c|c|c|c|c|c|c|c|c|c|c|c|c|c|}
\hline & \multicolumn{2}{|c|}{ S1 } & \multicolumn{2}{|c|}{ S2 } & \multicolumn{2}{|c|}{ S3 } & \multicolumn{2}{|c|}{ S4 } & \multicolumn{2}{|c|}{ S5 } & \multicolumn{2}{|c|}{ S6 } & \multicolumn{2}{|c|}{ S7 } & \multicolumn{2}{|c|}{ S8 } \\
\hline & I. W. & S. W. & I. $W$. & S. W. & I. W. & S. W. & I. W. & S. W. & I. $W$. & S. W. & I. $W$. & S. W. & 1. W. & S. W. & I. W. & S. W. \\
\hline Temp $\left({ }^{\circ} \mathrm{C}\right)$ & 26.74 & 26.86 & 26.73 & 26.66 & 26.79 & 26.53 & 27.17 & 27.45 & 26.63 & 26.50 & 31.68 & 31.70 & 31.98 & 32.03 & 31.26 & $\overline{31.22}$ \\
\hline $\min$ & 25.60 & 25.70 & 24.50 & 24.50 & 25.10 & 25.60 & 23.70 & 23.70 & 23.10 & 23.10 & 28.60 & 28.60 & 30.10 & 30.10 & 28.50 & 28.50 \\
\hline $\max$ & 28.00 & 28.00 & 29.00 & 29.00 & 28.00 & 27.30 & 30.00 & 30.00 & 28.30 & 28.30 & 33.00 & 33.00 & 33.00 & 33.00 & 32.10 & 32.10 \\
\hline $\mathrm{SD}$ & 0.72 & 0.75 & 1.22 & 1.17 & 0.81 & 0.57 & 2.17 & 2.17 & 1.42 & 1.47 & 1.07 & 1.12 & 0.78 & 0.85 & 0.98 & 1.05 \\
\hline $\mathbf{p H}$ & 7.20 & 7.29 & 7.26 & 7.25 & 7.28 & 7.25 & 7.75 & 7.88 & 7.34 & 7.42 & 7.39 & 7.63 & 7.65 & 7.67 & 7.38 & 7.48 \\
\hline $\min$ & 6.90 & 6.90 & 6.80 & 6.80 & 6.80 & 6.80 & 7.00 & 7.00 & 6.90 & 6.90 & 7.10 & 7.10 & 7.05 & 7.05 & 6.90 & 6.90 \\
\hline $\max$ & 7.43 & 7.97 & 7.54 & 7.49 & 7.52 & 7.51 & 8.29 & 8.29 & 7.70 & 7.70 & 7.92 & 7.93 & 7.97 & 7.97 & 7.74 & 7.76 \\
\hline SD & 0.15 & 0.31 & 0.20 & 0.22 & 0.21 & 0.24 & 0.36 & 0.40 & 0.23 & 0.28 & 0.26 & 0.29 & 0.29 & 0.31 & 0.28 & 0.30 \\
\hline Cond. ( $\mu \mathrm{s} . \mathrm{cm}^{-1}$ ) & 820.0 & 819.7 & 816.1 & 816.6 & 815.6 & 815.7 & 1453 & 1452 & 1134 & 1016 & 1149 & 1130 & 1138 & 1141 & 1101 & 1112 \\
\hline $\min$ & 813.0 & 813.0 & 797.0 & 803.0 & 803.0 & 803.0 & 1387 & 1387 & 961 & 873 & 1131 & 1056 & 1100 & 1119 & 1037 & 1037 \\
\hline $\max$ & 844.0 & 844.0 & 832.0 & 832.0 & 833.0 & 833.0 & 1545 & 1545 & 1304 & 1208 & 1253 & 1150 & 1158 & 1158 & 1193 & .1197 \\
\hline SD & 7.69 & 8.02 & 7.86 & 6.18 & 7.19 & 6.63 & 54.87 & 55.73 & 111. & 112.3 & 31.64 & 31.71 & 14.64 & 9.51 & 38.97 & 49.64 \\
\hline$O 2\left(\mathrm{mg} \cdot 1^{-1}\right)$ & 3.48 & 3.33 & 3.55 & 3.30 & 3.22 & 3.14 & 0.52 & 3.34 & 0.74 & 3.53 & 2.87 & 3.62 & 3.21 & 3.55 & 2.51 & 3.49 \\
\hline $\min$ & 1.40 & 1.40 & 1.50 & 1.50 & 1.30 & 1.30 & 0.10 & 2.60 & 0.20 & 3.00 & 1.20 & 3.20 & 1.20 & 280 & 0.90 & 3.00 \\
\hline $\max$ & 4.80 & 4.80 & 5.10 & 5.10 & 4.50 & 4.50 & 1.40 & 3.80 & 1.40 & 4.10 & 3.90 & 4.30 & 4.70 & 4.50 & 4.30 & 4.20 \\
\hline SD & 1.15 & 1.20 & 1.20 & 1.18 & 1.04 & 1.01 & 0.42 & 0.34 & 0.41 & 0.38 & 0.97 & 0.34 & 1.06 & 0.43 & 1.25 & 0.36 \\
\hline TAC mg. & 345.9 & 347 & 345.2 & 344.2 & 340.9 & 333.5 & 378.3 & 377.6 & 366.7 & 359.2 & 329.2 & 332.6 & 338.8 & 338.8 & 337.0 & 338.8 \\
\hline $\begin{array}{l}\mathrm{CaCO}_{3}^{-} \mathrm{1}^{-1} \\
\min \end{array}$ & 302.6 & 302.6 & 305.0 & 305.0 & 292.8 & 278.2 & 329.4 & 329.4 & 280.6 & 280.6 & 297.7 & 297.7 & 309.9 & 309.9 & 280.6 & 297.7 \\
\hline $\max$ & 402.6 & 402.6 & 390.4 & 405.1 & $395.3^{\circ}$ & 397.7 & 456.3 & 456.3 & 431.9 & 397.7 & 390.4 & 414.8 & 385.5 & 390.4 & 385.5 & 388.0 \\
\hline $\mathrm{SD}$ & 25.76 & 30.61 & 21.91 & 23.94 & 27.74 & 33.27 & 43.63 & 45.82 & 35.06 & 32.38 & 31.35 & 35.66 & 24.23 & 27.53 & 29.85 & 27.91 \\
\hline THT (meq. $1^{-1}$ ) & 5.97 & 6.25 & 6.30 & 6.28 & 6.18 & 5.98 & 6.48 & 6.78 & 6.40 & 6.85 & 6.60 & 6.94 & 6.16 & 6.38 & 6.45 & 6.20 \\
\hline $\min$ & 4.40 & 4.80 & 4.20 & 4.16 & 4.60 & 3.24 & 3.24 & 3.24 & 5.03 & 4.72 & 4.60 & 5.12 & 4.48 & 4.48 & 5.00 & 5.00 \\
\hline $\max$ & 8.00 & 7.48 & 8.60 & 8.60 & 7.80 & 7.20 & 9.80 & 9.00 & 8.00 & 9.00 & 8.00 & 8.28 & 8.00 & 7.80 & 9.40 & 7.60 \\
\hline $\mathrm{SD}$ & 1.08 & 0.77 & 1.36 & 1.18 & 0.89 & 1.01 & 1.64 & 1.58 & 1.09 & 1.28 & 1.04 & 0.78 & 1.16 & 0.99 & 1.22 & 0.78 \\
\hline
\end{tabular}


Table 1. continued.

Tableau 1. suite.

\begin{tabular}{|c|c|c|c|c|c|c|c|c|c|c|c|c|c|c|c|c|}
\hline & \multicolumn{2}{|c|}{$\mathbf{S 1}$} & \multicolumn{2}{|c|}{$\mathbf{S 2}$} & \multicolumn{2}{|c|}{$\mathbf{S 3}$} & \multicolumn{2}{|c|}{ S4 } & \multicolumn{2}{|c|}{ SS } & \multicolumn{2}{|c|}{ S6 } & \multicolumn{2}{|c|}{ S7 } & \multicolumn{2}{|c|}{$\mathbf{S 8}$} \\
\hline & 1. W. & s. W. & I. W. & S. W. & I. W. & S. W. & I. W. & S. W. & I. W. & S. W. & I. W. & s. w. & I. W. & S. W. & I. W. & S. W. \\
\hline $\mathrm{Ca}^{2+}\left(\mathrm{mg} \cdot \mathrm{I}^{-1}\right)$ & 71.05 & 70.00 & 68.34 & 72.58 & 7243 & 69.60 & 80.35 & 76.23 & 70.15 & 71.88 & 74.00 & 75.38 & 73.78 & 70.47 & 73.09 & 72.00 \\
\hline $\min$ & 56.00 & 48.00 & 48.00 & 58.40 & 64.00 & 60.00 & 71.20 & 56.00 & 56.00 & 56.00 & 60.00 & 64.00 & 64.00 & 52.00 & $\$ 6.00$ & 36.00 \\
\hline $\max$ & 88.40 & 88.40 & 91.20 & 91.20 & 88.40 & 88.40 & 108.0 & 91.20 & 101.0 & 100.0 & 90.00 & 92.00 & 88.00 & 88.00 & 93.60 & 93.60 \\
\hline SD & 10.32 & 12.70 & 11.75 & 8.94 & 8.89 & 9.47 & 10.02 & 9.03 & 12.93 & 13.01 & 10.57 & 8.98 & 7.65 & 10.05 & 12.62 & 12.09 \\
\hline $\mathrm{SO}_{4}{ }^{2-}\left(\mathrm{mg} \cdot \mathrm{l}^{-1}\right)$ & 18.07 & 16.53 & 17.86 & 16.59 & 17.65 & 15.58 & 32.28 & 33.55 & 23.93 & 23.04 & 26.23 & 23.05 & 22.85 & 23.54 & 24.16 & 23.49 \\
\hline $\min$ & 11.19 & 7.38 & 13.57 & 7.38 & 12.77 & 4.84 & 16.26 & 16.26 & 15.63 & 13.88 & 15.15 & 16.42 & 11.19 & 12.93 & 16.74 & 15.79 \\
\hline $\max$ & 28.96 & 28.96 & 27.22 & 27.20 & 27.69 & 27.22 & 48.65 & 48.65 & 31.34 & 31.34 & 41.66 & 28.17 & 35.63 & 35.63 & 29.12 & 29.12 \\
\hline $\mathrm{SD}$ & 4.91 & 6.79 & 4.95 & 5.69 & 4.76 & 6.78 & 10.61 & 11.60 & 4.83 & 5.33 & 6.49 & 4.23 & 6.73 & 6.44 & 3.35 & 4.04 \\
\hline Cl- (mg. $\left.\left.\right|^{-1}\right)$ & 106.1 & 111.8 & 99.6 & 105.5 & 110.3 & 105.9 & 274.3 & 272.7 & 176.6 & 164.7 & 205.6 & 210.0 & 201.2 & 198.8 & 187.8 & 197.0 \\
\hline $\min$ & 78.1 & 85.2 & 63.9 & 63.9 & 85.2 & 85.2 & 213.0 & 213.0 & 134.9 & 99.4 & 163.3 & 170.4 & 149.1 & 149.1 & 163.3 & 163.3 \\
\hline $\max$ & 142.0 & 142.0 & 142.0 & 142.0 & 170.4 & 142.0 & 355.0 & 319.5 & 220.1 & 220.1 & 266.2 & 266.2 & 280.0 & 248.5 & 248.0 & 284.0 \\
\hline SD & 20.5 & 21.8 & 20.4 & 24.0 & 25.8 & 15.5 & 35.6 & 32.9 & 26.8 & 32.1 & 26.65 & 32.4 & 33.7 & 29.4 & 24.2 & 35.4 \\
\hline $\mathrm{PO}_{4}{ }^{3-}\left(\mathrm{mg} \cdot \mathrm{l}^{-1}\right)$ & 0.03 & 0.06 & 0.03 & 0.02 & 0.02 & 0.01 & 0.14 & 0.16 & 0.05 & 0.03 & 0.02 & 0.02 & 0.03 & 0.01 & 0.03 & 0.02 \\
\hline $\min$ & 0.00 & 0.00 & 0.00 & 0.00 & 0.00 & 0.00 & 0.02 & 0.02 & 0.00 & 0.00 & 0.00 & 0.00 & 0.00 & 0.00 & 0.00 & 0.00 \\
\hline $\max$ & 0.13 & 0.39 & 0.23 & 0.10 & 0.08 & 0.05 & 0.44 & 0.44 & 0.27 & 0.12 & 0.10 & 0.10 & D. 08 & 0.10 & 0.10 & 0.06 \\
\hline SD & 0.04 & 0.11 & 0.06 & 0.03 & 0.03 & 0.01 & 0.14 & 0.14 & 0.08 & 0.04 & 0.03 & 0.03 & 0.03 & 0.03 & 0.03 & 0.02 \\
\hline $\mathrm{NO}_{3}{ }^{2-}\left(\mathrm{mg} \cdot \mathrm{I}^{-1}\right)$ & 19.99 & 21.36 & 16.15 & 17.94 & 16.40 & 19.10 & 2.67 & 5.73 & 4.21 & 9.89 & 12.59 & 13.67 & 14.75 & 13.28 & 8.25 & 8.72 \\
\hline $\min$ & 6.80 & 6.65 & 4.30 & 6.87 & 3.85 & 4.61 & 0.00 & 0.00 & 0.00 & 0.00 & 0.00 & 0.00 & 6.50 & 1.95 & 4.00 & 3.40 \\
\hline $\max$ & 32.58 & 41.13 & 25.92 & 25.92 & 24.11 & 32.58 & 9.14 & 14.21 & 13.22 & 39.38 & 28.19 & 28.19 & 22.90 & 22.90 & 13.30 & 15.27 \\
\hline SD & 7.21 & 8.48 & 7.64 & 6.48 & 7.45 & 7.40 & 2.76 & 4.73 & 4.15 & 10.29 & 7.41 & 7.41 & 5.26 & 6.24 & 3.13 & 3.61 \\
\hline
\end{tabular}

Rodier (1996). Alkalinity (TAC) was measured by the titrimetric method using sulfuric acid (N/50) in presence of bromocresol green and methyl red. It is expressed as $\mathrm{mg}$. $\mathrm{CaCO} 3 \mathrm{l}^{-1}$. Total hardness and calcium concentrations were measured, with the EDTA complexometric method and are expressed, as meq. $\mathrm{l}^{-1}$ and mg. $\mathrm{l}^{-1}$. Chlorides were measured with silver nitrate in the presence of potassium chromate and are expressed as mg. $\mathrm{l}^{-1}$. Sulphates were measured by the nephelometric method and expressed as mg. $\mathrm{l}^{-1}$. Orthophospates were measured with ammonium molybdate and expressed as mg..$^{-1}$. Nitrates were measured with sodium salicylate method and expressed as mg. $\mathrm{I}^{-1}$.

For analysis between means, a t test was used.

\section{Results}

\subsection{Physical and chemical parameters}

\section{Mean values}

The different results are given in the Table 1 (means, ranges and standard deviations) and represented on Fig. 3.
Except for disolved oxygen and nitrates from stations S4 and S5, the mean values did not differ between interstitial and superficial waters.

The temperature varied strongly between the stations : from about $26.7^{\circ} \mathrm{C}$ at stations S1, S2, S3, and $\mathrm{S} 5$, to $31.7^{\circ} \mathrm{C}$ at stations $\mathrm{S} 6, \mathrm{~S} 7$ and S8. Intermediary values were obtained in the station $\mathrm{S} 4\left(27.3^{\circ} \mathrm{C}\right)$ and in the station $\mathrm{S} 8\left(31.2^{\circ} \mathrm{C}\right)$.

The $\mathrm{pH}$ values were near neutrality at stations $\mathrm{S} 1$, S2, and S3 (about 7.2) and higher in the other ones. The higher values were obtained in the station S4 (about 7.8).

The conductivity was high in the «hot spring» and in oued Sidi Harazem (1100 to $\left.1500 \mu \mathrm{S} . \mathrm{cm}^{-1}\right)$. In contrast, the «cool springbrook» showed lower values (about $820 \mu \mathrm{S} . \mathrm{cm}^{-1}$ ), which however indicated a relatively bad water quality (Brémond \& Perrodon 1979).

The oxygen values were low, especially in the ground water of stations S4 and S5, which created hypoxic conditions in the substratum (respectively 0.52 

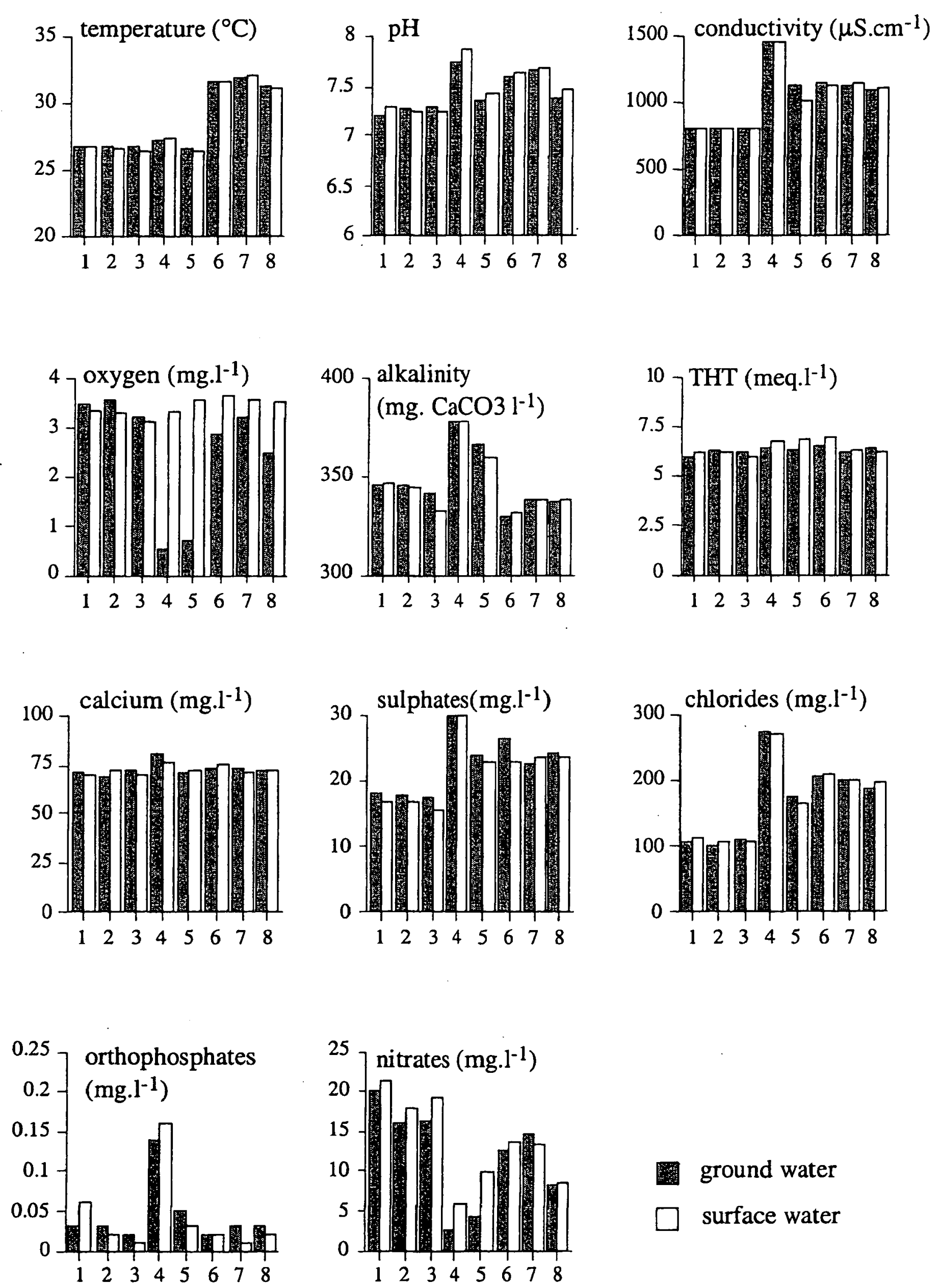

ground water
$\square \quad$ surface water

Fig. 3. Mean values of the environmental parameters in both ground and surface waters. See Table 1 for details of values.

Fig. 3. Valeurs moyennes des paramètres du milieu dans les eaux interstitielles et les eaux de surface. Cf. Tableau 1 pour le détail des valeurs. 
and $0.74 \mathrm{mg} . \mathrm{l}^{-1}$ ). Other values ranged from 2.51 (S8) to $3.62 \mathrm{mg} . \mathrm{l}^{-1}$ (S6).

Alkalinity (TAC) mostly ranged from 330 (S6) to $346 \mathrm{mg}$. CaCO3- $\mathbf{1}^{-1}$ (S1) but the values of S4 and S5 were higher ( 359 to $378 \mathrm{mg}$. CaCO3- $\left.{ }^{-1}\right)$.

Total hardness (THT) and calcium showed very similar values, closed to 6.5 meq..$^{-1}$ for THT, and 72 mg. $\mathrm{l}^{-1}$ for calcium.

Sulphates, chlorides and orthophosphates showed the highest values at station $\mathrm{S} 4$, and the lowest at stations S1, S2 and S3.

In contrast, nitrate values were lowest at station $\mathrm{S} 4$ (less than $5 \mathrm{mg} . ~^{-1}$ ) and highest at stations S1, S2 and S3.

These results allow to charaterize three types of stations in this site and the relationships between the three types of water : stations 1,2 and 3 ; stations 4 and 5 ; stations 6, 7 and 8 (Fig. 3).

The water from the "cool stream" showed the lowest conductivity (about $800 \mu \mathrm{S} . \mathrm{cm}^{-1}$ ) and the lowest chloride content (about $100 \mathrm{mg} . ~^{-1}$ ).

The water of the "hot stream" showed the highest temperature $\left(32^{\circ} \mathrm{C}\right)$ and a high conductivity (1150 $\mu \mathrm{S} . \mathrm{cm}^{-1}$ ).

The water of oued Sidi Harazem (station 4 and sometimes also 5 which is influenced by both the oued and the «cool spring») showed the highest values for $\mathrm{pH}$ (about 7.5), conductivity $\left(1450 \mu \mathrm{S} . \mathrm{cm}^{-1}\right)$, alkalinity (302 mg. CaCO3 $\mathrm{l}^{-1}$ ), chlorides (260 mg.1 $\mathrm{l}^{-1}$ ), calcium (about $85 \mathrm{mg} . \mathrm{l}^{-1}$ ), and sulphates $\left(35 \mathrm{mg} . \mathrm{l}^{-1}\right.$ ) but also the lowest values for magnesium (about $17 \mathrm{mg} . \mathrm{l}^{-1}$ ).

On the basis of these results, it is possible to study the temporal changes of the parameters in the three types of stations.

\section{Changes versus time (Fig. 4)}

In all the stations, temperature increased from spring to summer and then decreased, especially for those least influenced by the springs, S4 and S5. The temperature of the spring water was less variable. Except in stations S4 and S5 (oued Sidi Harazem) there was no clear winter minimum.

The reverse was observed for $\mathrm{pH}$ with the lowest values in spring. The values were less variable downstream from the "cool spring". Except in the first sampling (15/4/1998) a general tendancy to increasing was observed all along the study period.

Dissolved oxygen which did not change in stations S4 and S5, showed lower values in autumn (the high first values were not explained).
Conductivity was very stable downstream from the springs, but variable with an inversion of the values in summer and autumn" for stations S4 and S5. To a certain extent, chlorides showed identical changes with, however, greater amplitude.

Total hardness showed the highest variations with the highest values during spring and the lowest values during summer and autumn.

Similar but slightly attenuated data were observed for calcium at stations S4 to S8. At station S1 to S3, values were higher in spring 1998, then decreased and remained stable.

The values for sulfates were highly variable especially in the stations S4 and S5. The higher value was observed in winter at station $\mathrm{S} 4$.

The values for nitrates were also highly variable at stations S1 to S3 and S6 to S8. They were relatively stable at stations $\mathrm{S} 4$ and S5.

Except for S4 which showed variable values at the beginning of the observations, the orthophosphates, not shown in Fig. 4, remained at a low level (between 0.01 and $0.4 \mathrm{mg} . \mathrm{l}^{-1}$ at stations S4 and S5, and 0.01 and 0.2 at other stations).

Except for stations S4 and S5 which appeared slightly variable (about $300 \mathrm{mg}$. $\mathrm{CaCO} 3 \mathrm{l}^{-1}$ ), the values for alkalinity were quite stable with a very light decrease in winter 1999 (not shown in Fig. 4).

\subsection{Faunal characteristics (Table 2)}

The interstitial fauna of this study was composed of both epigean and hypogean (stygobite) species, and as for physical and chemical parameters it is possible to distinguish three types of stations. Aquatic Oligochaeta, and the epigean Mollusca Melanopsis praemorsa were the most abundant organisms, especially at stations S4 and S5.

With 8 species the springbrook "cool stream" stations $S 1$ to S3 were the richest in stygobite species (2 Gastropoda, 1 Amphipoda and 2 Isopoda). Stations S4 and S5 were characterized by numerous polysaprobiontic species which are usually present in polluted waters. The downstream "hot stream" stations S6 to S8 were the most diversified, but with only 1 stygobite species (one Syncarida in station S6: Paraiberobathynella maghrebensis Camacho \& Serban, 1998). The other species were those of well oxygenated water.

The distribution within the sediment of stations $\mathrm{S} 1$, S2 and S3 was characterized by an increasing number of the stygobite Microcharon and Typhlocirolana sp. with depth (Fig. 5), the stygobite Pseudoniphargus sp. was distributed regularly with depth and the epigean 


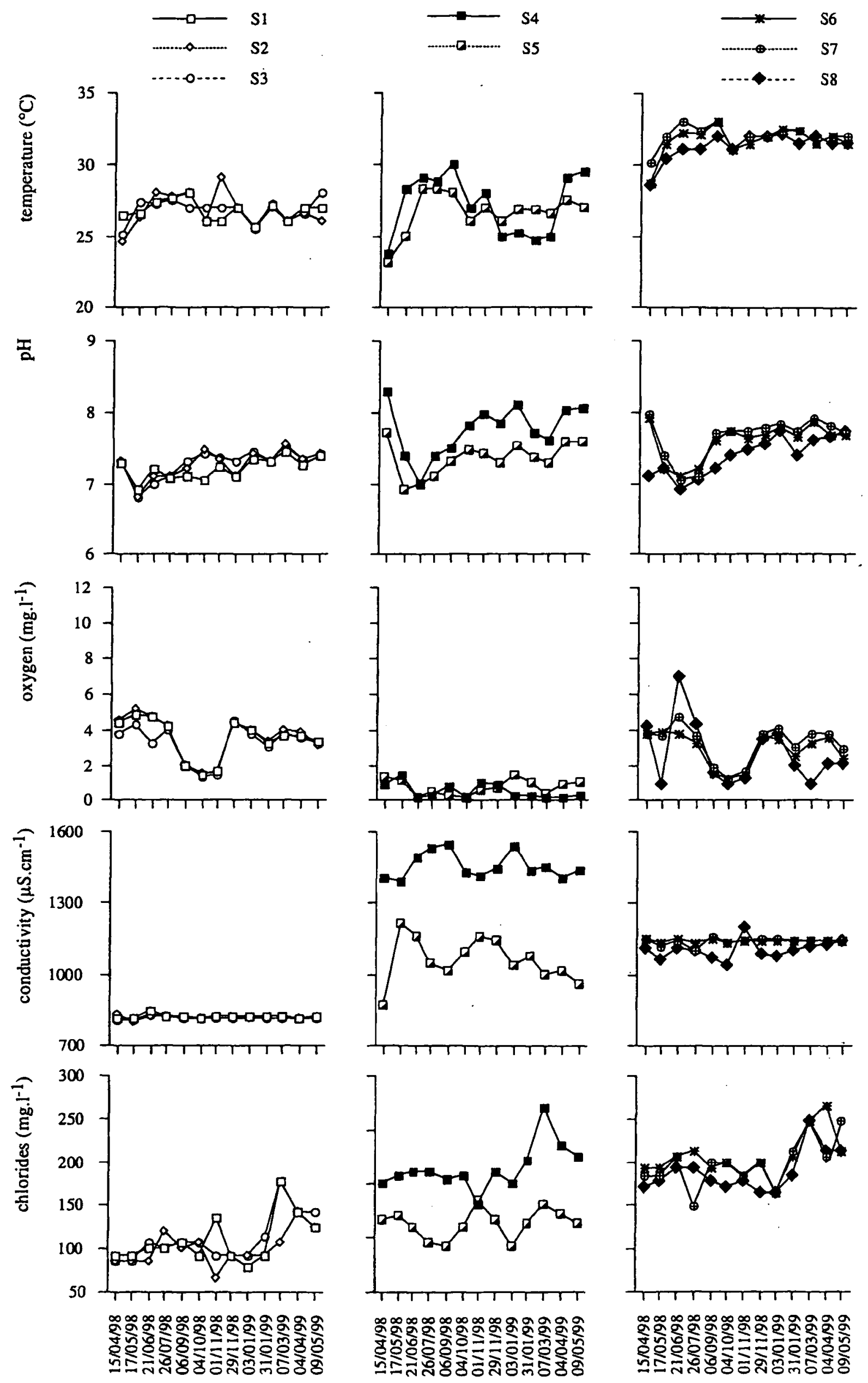

Fig. 4. Dynamics of environmental parameters during the study (from April 1998 to May 1999). Fig. 4. Dynamique des paramètres du milieu au cours de l'étude - d'avril 1998 à mai 1999 -. 


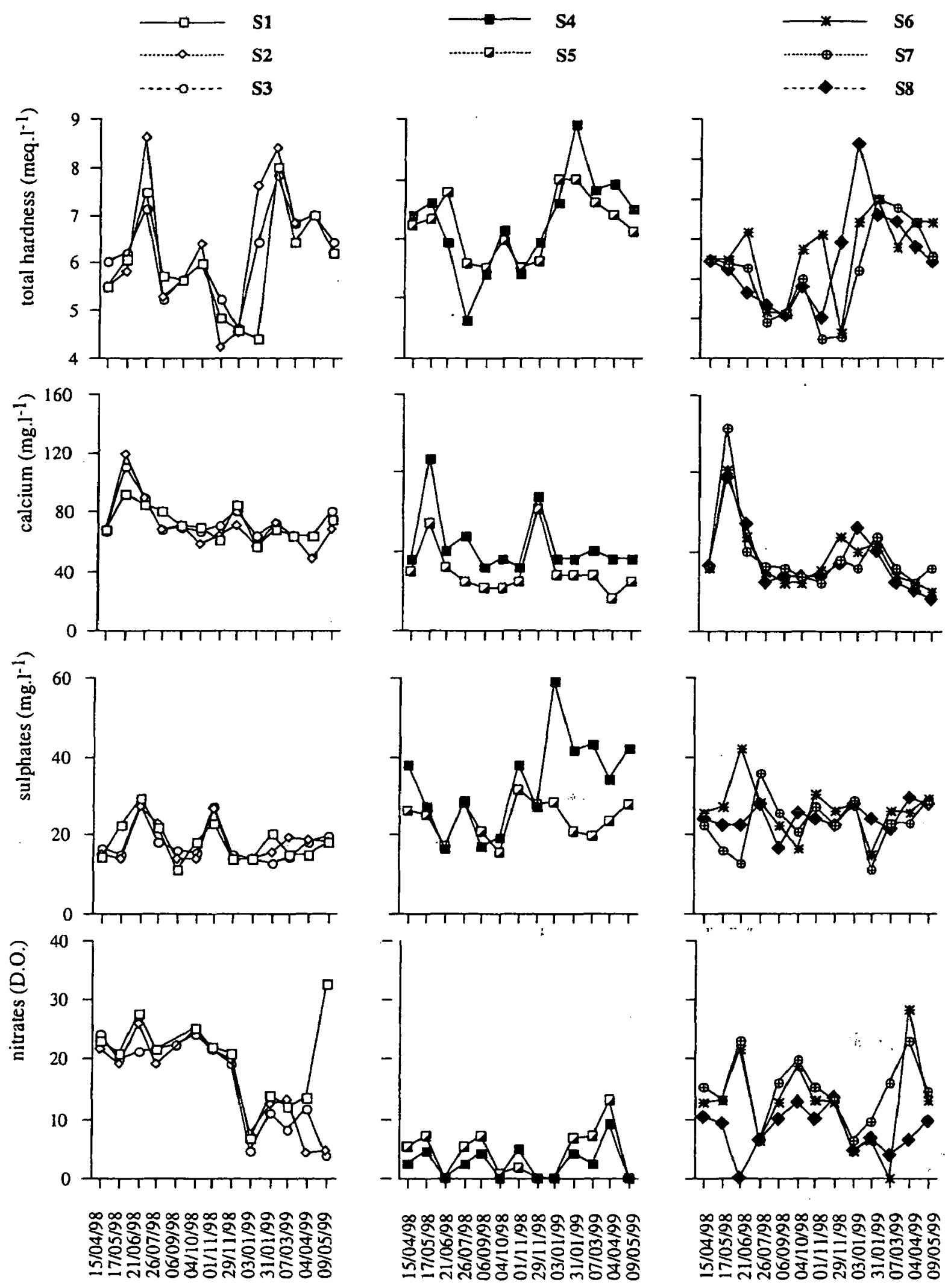

Fig. 4. continued.

Fig. 4. suite. 
Table 2. Total number of each taxon sampled during the study.

Tableau 2. Nombre total de chaque taxon récolté pendant l'étude.

\begin{tabular}{|c|c|c|c|c|c|c|c|c|}
\hline Taxa & S1 & $\mathbf{S 2}$ & S3 & S4 & S5 & S6 & S7 & S8 \\
\hline \multicolumn{9}{|l|}{ ANNELIDA } \\
\hline \multicolumn{9}{|l|}{ Achaeta } \\
\hline Glossiphonia sp. & & & & 154 & 70 & & & \\
\hline \multicolumn{9}{|l|}{ Oligochaeta } \\
\hline Tubifex sp. & & & & 1672 & 600 & & 10 & 24 \\
\hline \multicolumn{9}{|l|}{ MOLLUSCA } \\
\hline \multicolumn{9}{|l|}{ Gastropoda } \\
\hline Melanopsis praemorsa & 7 & 5 & 22 & 356 & 200 & 186 & 58 & 100 \\
\hline Physa acuta & & & & 20 & & & 10 & 8 \\
\hline Theodoxia sp. & & 13 & 1 & & & & & \\
\hline Horatia aghbalensis* & 5 & 15 & & & & & & \\
\hline Heideela knidiri* & 2 & & & & & & & \\
\hline \multicolumn{9}{|l|}{ ARTHROPODA } \\
\hline \multirow{2}{*}{\multicolumn{9}{|c|}{$\begin{array}{l}\text { CRUSTACEA } \\
\text { Amphypoda }\end{array}$}} \\
\hline & & & & & & & & \\
\hline Pseudoniphargus maroccanus* & 9 & 68 & 33 & & & & & \\
\hline \multicolumn{9}{|l|}{ Isopoda } \\
\hline Typhlocirolana fontis (aff)* & 9 & 68 & 33 & & & & & \\
\hline Microcharon alamiae* & 51 & 54 & 61 & & & & & \\
\hline \multicolumn{9}{|l|}{ Ostracoda } \\
\hline Danwinulla sp. & & & & & & 3 & 4 & \\
\hline Stenocypris $\mathrm{sp}$. & & & & & & 27 & 96 & 5 \\
\hline \multicolumn{9}{|l|}{ Copepoda Cyclopoida } \\
\hline Paracyclops fimbriatus & & 10 & 2 & & & 4 & 10 & 6 \\
\hline Acanthocyclops robustus (?) & & & & & & 1 & & \\
\hline Cladocera & & . & & & & 21 & 7 & \\
\hline \multicolumn{9}{|l|}{ Syncarida } \\
\hline $\begin{array}{l}\text { Paraiberobathynella } \\
\text { (maghrebensis)* }\end{array}$ & & & & & & 3 & & \\
\hline \multicolumn{9}{|l|}{ INSECTA } \\
\hline Ephemeroptera & & 4 & & & 5 & 9 & 20 & 15 \\
\hline Odonata & & & & & & 6 & 11 & 18 \\
\hline Trichoptera & & & & & 3 & & & \\
\hline Diptera & & 1 & 1 & 12 & 5 & 9 & 13 & 7 \\
\hline Number of taxa & 6 & 10 & 7 & 5 & 6 & 10 & 10 & 9 \\
\hline Number of stygobite species $\left({ }^{*}\right)$ & 5 & 4 & 3 & & & 1 & & \\
\hline
\end{tabular}



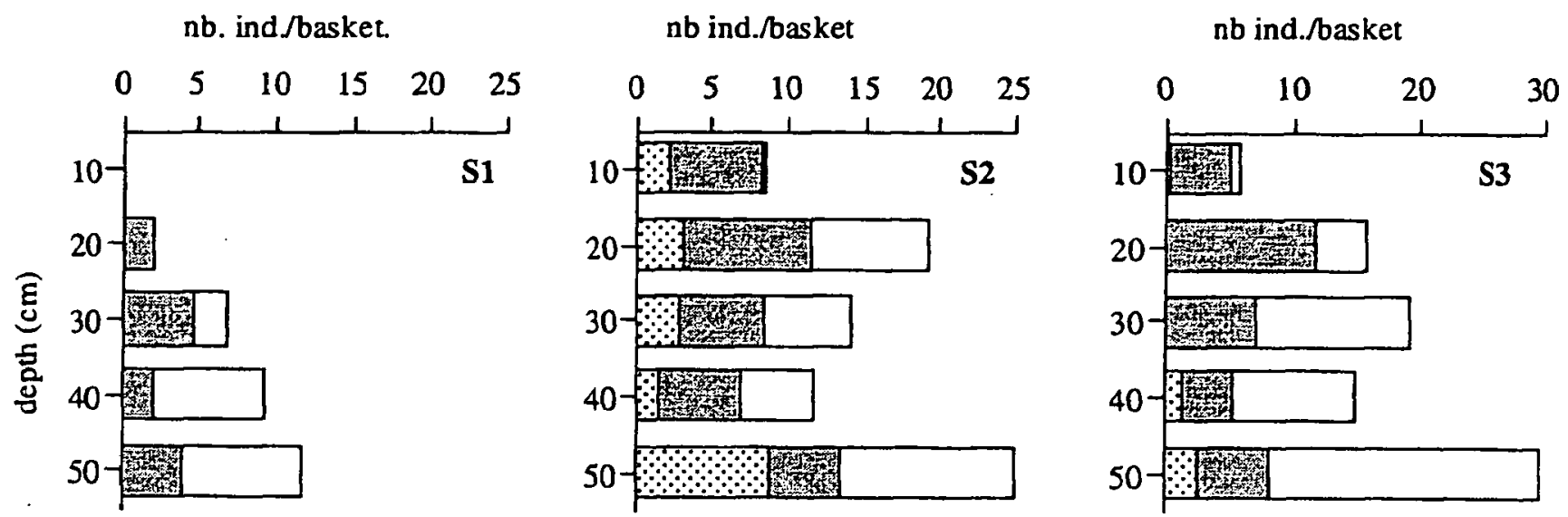

Typhlocirolana sp.

四 Pseudoniphargus sp.

Microcharon sp.
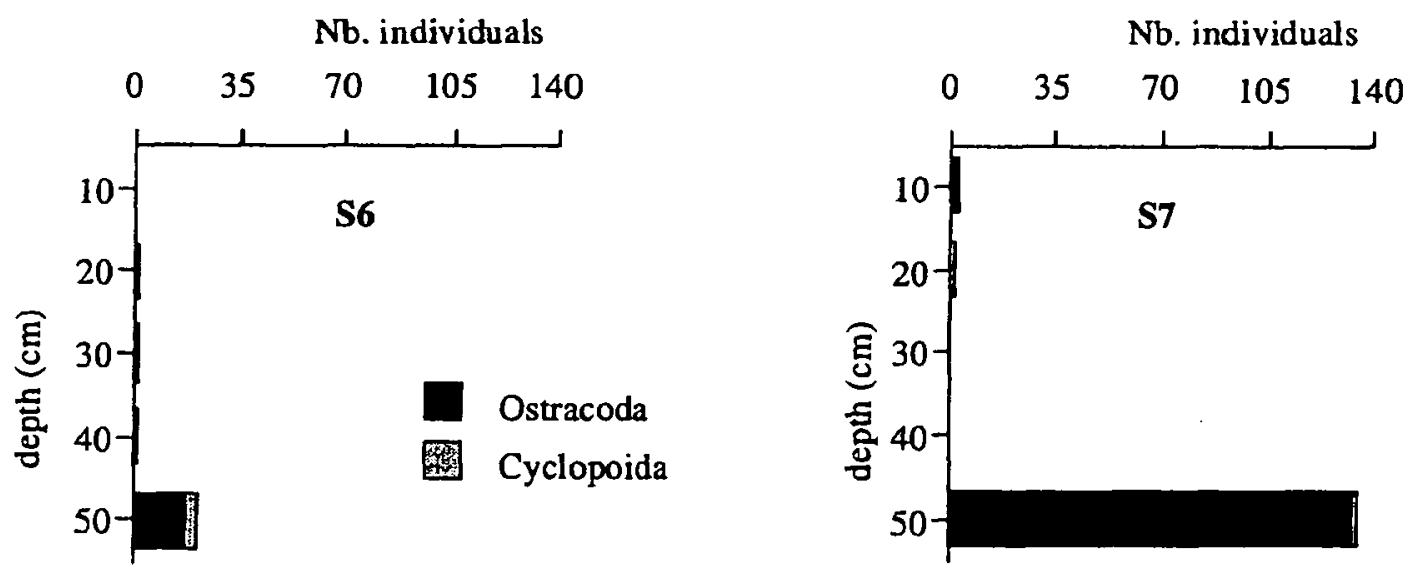

Fig. 5. Changes in number of stygobite species (Typhlocirolana, Pseudoniphargus and Microcharon) at stations S1, S2, and S3, and Microcrustacea (Ostracoda and Copepoda) at stations S6 and S7 versus depth.

Fig. 5. Evolution des nombres d'espèces stygobies (Typhlocirolana, Pseudoniphargus, Microcharon) dans les stations S1, S2, and S3 et des Microcrustacea (Ostracoda et Copepoda) aux stations S6 et S7 selon la profondeur.

species showed a decreasing number with depth. An increasing number of Ostracoda and Cyclopoida with depth was observed at stations S6 and S7.

\section{Discussion and conclusion}

The goal of this study was to analyse the relationships between ecological parameters (such as physical and chemical characteristics of water, depth within the sediment), and interstitial community in the complex hydrological system of the Sidi Harazem springs by using artificial substrates buried within the sediment.

The characteristics of the physical and chemical parameters of the water of the sprinbrooks and their changes varied with the location where the measures were taken, and their differences might simply be due to the fact that their groundwater originated from a general aquifer flowing in various types of sediment and/or meeting thermal water. The water collected from the bottom of the wells was perhaps not pure groundwater, as it had been stirred during the removal of the baskets. It may have been a mixture of surface and ground water (Naamane et al. 2000).

Since the values of $\mathrm{Ca}$ concentration were the same, which proves that the water of all the stations flowed through the same calcareous or dolomitic rocks (Combe 1975), the water of stations S6 and S7 issuing from the "hot spring", with high chloride concentrations which induce a high conductivity, certainly flows through saline or rests in contact with marly rocks. The influence of this "hot spring" was especially obvious downstream from the station S5. Thus, temperature, conductivity, sulphates and nitrates acted on station S8 by increasing their values when compared to stations S4 and S8 of the oued. The very low values of groundwater dissolved oxygen at station 5 certainly depends 
on the small distance which separates it from polluted station S4. This parameter was easily restored under the influence of the «hot spring» and well oxygenated water. The low values of nitrates at stations S4 and S5 are certainly due to the relative lack of oxygen. Nevertheless, at station S4 appeared to be the most different from the others and more polluted by sulphates, chlorides, and orthophosphates. The water of station S5, very near downstream and directly influenced by it, was rapidly restored by the water of the "cool spring brook".

The values of these environmental parameters are either the same as or different from those obtained by Essafi et al. (1993, 1998) in oued Zeghzel and in the artesian wells of the Fès area. Except for stations S4 and S5 which are under direct influence of the oued and its fluctuations, the temperature appeared to be stable versus time i.e. buffered by the subterranean milieu. The $\mathrm{pH}$ values are very comparable with those of previous studies, either in France or in Morocco (Essafi-Chergui 1990, Essafi et al. 1993, 1998), and this relative neutrality is characteristic of water flowing in limestone areas. The conductivity which appeared higher than that obtained by Essafi et al. $(1993,1998)$ in classical Moroccan waters, seems to be characteristic of hot spring water (Glazier 1991). These high values, certainly due to those of chlorides, are however within the standards of drinking water $(<250 \mathrm{mg} / \mathrm{l}$ : Brémond \& Perrodon 1979).

The number of taxa in the sediment of this site was not very high (20 taxa), and appeared identical for the "hot" (12 taxa) and the "cool (11 taxa)" springbrooks, but the species were not exactly the same. Moreover, few insect taxa were found. The number of taxa of stations S4 and S5 was especially low (respectively 5 and 6 taxa). These were predators, scrapers and collectors. The other stations were more diversified, and it seems that stygobite species only present in the cool brook gave more information on water quality than epigean species.

Hayford \& Herrmann (1998) and Lamberti \& Resh (1983) demonstrated that temperature affects macroand micro-invertebrate distribution more than chemical composition in hot springs that do not reach chemical extremes. Such a model of faunal distribution applies to this study, which did not show chemical extremes, and where more taxa were found in the "hot" than in the "cool springbrook". but presented stygobite species quite only in the sediment of the "cool spring" and its springbrook. Moreover, stygobite species occurred only in the sediment of the "cool spring" and its springbrook, i.e. stations S1 to S3. The presence of the stygobite Paraiberobathynella maghrebensis (Camacho \& Serban 1998) at station S6 may be explained as this species may be thermophilic. Thermophiles are those species commonly found in thermal springs but they are not limited to them (Hayford \& Herrmann 1998). Such is the case of the Ostracoda Stenocypris sp. (Petkovski \& Meisch 1996) found at stations S6 to S8.

Glazier (1991) explained why non-insect taxa are prevalent in springs. This author argued that the physical stability, especially the thermal constancy and the absence or rarity of defaunating spates or droughts in permanent springs, may favour non-emergent lifestyles, but also that these taxa are dependent on water $\mathrm{pH}$ and alkalinity, the proportion of non-insect invertebrate orders in spring water increasing significantly with rising $\mathrm{pH}$ and alkalinity. Such a hypothesis could be adapted to the interstitial fauna of the present study and could explain the rarity of insect taxa (especially of the Trichoptera which are generally numerous in springs : Robert 1998, Cianficconi et al. 1998) and their low abundance compared to those of non-insect taxa (Gastropoda, Crustacea). The high values of alkalinity ( $>250 \mathrm{mg} . \mathrm{l}^{-1}$ ) may partly explain the rarity of insects and the relative abundance of other invertebrates.

Stygobite taxa generally appear more numerous in deep zones of the sediment while the distribution of ubiquist taxa such as Niphargus or Pseudoniphargus appears more homogenous within the same sediments (Dole 1985, Dole \& Chessel 1986, Dole-Olivier \& Marmonier 1992). The vertical distribution of fauna of this study shows a general increase in abundance with depth. This is especially clear with stygobite crustacean Isopoda (Typhlocirolana and Microcharon). This distribution could be related to a greater thermical stability and/or less organic mater with depth as demonstrated by Naamane et al. (2000) at the same site. In contrast, the Amphipoda Pseudoniphargus, which is certainly more ubiquistic, seems to be more regularly distributed. Nevertheless, this last observation does not agree with previous moroccan studies in which Pseudoniphargus numbers generally decreased with depth (Essafi 1997, 1999).

In conclusion, among the 8 stations of this study, stations S4 and S5 clearly differed from the other six by the low water quality and a consecutive relative weakness of the interstitial fauna characterized by the lack of stygobites species. Moreover, as the water temperature downstream from the springs does not induce very large differences in water quality, the faunal characteristics could be interpreted as dependent upon the temperature of the springs, i.e. on the characteristics of 
the water origin. Therefore, this work brings new data concerning environmental parameters and also the structure of interstitial communities in an area supplied by both hot and "normal" water.

\section{Acknowledgements}

A part of this work was undertaken within the French/Moroccan "Action intégrée" 97/115/SVS. We thank A. Camacho who identified the Syncarid species. We thank Pr. Eric Pattée for improving the manuscript. We are grateful to reviewers for their helpful comments.

\section{References}

Ben Aabidate B. 1994. - Contribution à l'étude hydrogéothermique du Maroc Nord-Occidental (Gharb, Rides et Saïs). Thèse. Doct., Université de Sfax (Tunisie) : 245 p.

Boutin C. \& Boulanouar M. 1984. - Premières données sur la faune des puits des environs de Marrakech (Maroc occidental). Verh. Intern. Verein. Limnol., $22: 1762-1765$.

Boutin C. \& Idbennacer B. 1989. - Faune stygobie du Sud de l'anti-Atlas marocain : Premiers résultats. Revue des sciences de l'eau, 2 : 891-904.

Boutin C. \& Messouli M. 1988. - Metacrangonyx gineti n. sp. d'une source du Haut-Atlas marocain et la famille des Metacrangonyctidae $\mathrm{n}$. fam. (Crustacés Amphipodes souterrains). Vie et Milieu, 38 (1) (1988) : 67-84.

Brémond R. \& Perrodon C. 1979. - Paramètres de la qualité des eaux. Ministère de l'Environnement et du cadre de vie (éd.) : $259 \mathrm{p}$.

Camacho A.I. \& Serban E. 1998. - Tribu des Iberobathynellini nov. Diagnoses des taxa nouveau (Parabathynellidae, Bathynellacea, Podophallocarida. Travaux de l'Institut de Spéologie Emile Racovitza, XXXIV (1995) : 15-75

Cianficconi F., Corallini C. \& Moretti G. P. 1998. - Trichopteran fauna of the italian springs. in : The biology of springs and springbrooks, L. Botosaneanu (ed.) Backhuys Publisher, Leiden : $125-140$

Combe M. 1975. - Ressources en eau du Maroc ; le couloir de FèsTaza. Tome 2. Ed. du serv. géol. du Maroc. Rabat : 75 p.

Dole M.-J. 1985. - Le domaine aquatique souterrain de la plaine alluviale du Rhône à l'est de Lyon, 2. Structure verticale des peuplements des niveaux supérieurs de la nappe. Stygologia, 3 : 270-291.

Dole M.-J. \& Chessel D. 1986. - Stabilité hydrique et biologique des milieux interstitiels. Cas de deux stations du Haut-Rhône. Annls Limnol., 22 : 69-81.

Dole-Olivier M.-J. \& Marmonier P. 1992. - Patch distribution of interstitial communities : prevailing factors. Freshwat. Biol., 27 : $177-191$.

Essafi-Chergui K. 1990. - Structure et transfert des peuplements aquatiques souterrains à l'interface karst-plaine alluviale. Thèse de doctorat Lyon1, France : 102 p.

Essafi K., J. Mathieu \& Berrady I. 1998. — Qualité de l'eau et de la faune au niveau de forages artésiens dans la plaine de Fès et la plaine des Béni-Sadden. Premiers résultats. Mém. Biospéol., 25 : 157-166.

Essafi K., Mathieu J. \& Chergui H. 1993. - Les paramètres physico-chimiques en tant que facteurs explicatifs des relations entre les eaux superficielles karstiques et interstitielles de l'oued Zeghzel (Maroc oriental). Mém. Biospéol., 20 : 81-89.

Essafi K., Mathieu J. \& Chergui H. 1997. - Variations des effectifs de populations interstitielles de Niphargus et de Pseudoniphargus (Amphipodes stygobies) à l'interface karst/plaine alluviale. Mém. Biospéol., 24 : 15-24.
Essafi K., Mathieu J. \& Chergui H. 1999. - Spatial and temporal variations of stygobite amphipod populations in interstitial aquatic habitat of karst/floodplain interfaces in France and Morocco. Annls Limnol., 35 : 133-139.

Gibert J. 1992. - Ground water ecology from the perspective of environnemental sustainability. First international conference on groundwater ecology. U. S. Environnemental Protection Agency American Water Ressources Association : $13 \mathrm{p}$.

Gibert J. , Marmonier P., Vannek V. \& Plénet S. 1995. - Hydrological exchange and sediment characteristics in a riverbank : relationship between heavy metals and invertebrate community structure. Can. J. Fish. Aquat. Sci., 52 : 2084-2097.

Glazier D. S. 1991. - The fauna of North American temperate cold springs : patterns and hypotheses. Freshwat. Biol., 26 : 527-542.

Hayford B. \& Herrmann S. J. 1998. - Migration patterns of four macroinvertebrates along a thermal spring rheocrene. In : The biology of springs and springbrooks, L. Botosaneanu (ed.), Backhuys Publisher, Leiden : 75-83.

Khalaf G. \& Tachet H. 1977. - La dynamique de colonisation des substrats artificiels par les macroinvertebrés d'un cours d'eau. Annls. Limnol., 13 : 169-190.

Lamberti G. \& Resh V. 1983. - Geothermal effects on stream benthos : separate influences of thermal and chemical components on periphyton and macroinvertebrates. Can. J. Fish. aquat. Sci., 40 : 1995-2009.

Laville H. 1974. - Utilisation de substrats artificiels pour l'étude de la faune macrobenthique de la zone littorale rocheuse des lacs de montagne. Annls. Limnol., 10 (2) : 163-172.

Magniez G. 1978. - Magniezia gardei n. sp. (Crustacea Isopoda Asellota) : un Stenasellide des eaux souterraines du Maroc sudoriental. Int. J. Speleol., $9: 321-329$.

Malard F., Plénet S. \& Gibert J. 1996a. - The use of invertebrates in ground water monitoring. A rising research field. SPRING 1996 GWMR : 103-113.

Malard F., Reygrobellet J. L., Mathieu J. \& Lafont M. 1996b. Biomonitoring groundwater contamination : application to a karst area in Southern France. Aquatic Sciences, 58 : 158-187.

Mathieu J., Debouzie D. \& Martin D. 1987. — Influence des conditions hydrologiques sur la dynamique d'une population phréatique de Niphargus rhenorhodanensis (Amphipode souterrain). Vie et Milieu, 37 : 193-200.

Mathieu J. \& Essafi-Chergui K. 1990. - Le peuplement aquatique interstitiel à l'interface karst/ plaine alluviale. 1. Cas d'une alimentation en eau essentiellement karstique. Mém. Biospéol., 17 : 113-122.

Naaname B., Chergui H. \& Pattée E. 2000. - Distribution de la matière organique particulaire (M.O.P.) et de la faune invertébrée au niveau des milieux aquatiques interstitiels du bassin du Sebou (Maroc central). Bull. Soc. Linn. Lyon, 69 (7) : 157-180.

Nisbet M. \& Verneaux J. 1970. - Composantes chimiques des eaux courantes. Discussion et proposition de classes en tant que bases d'interpretation des analyses chimiques. Annls. Limnol., 6 : 161-190.

Pesce G. L., Tetè P. \& De Simone M. 1981. - Richerche in Africa dell' Istituto di Zoologia de l'aquila. VI. Richerche faunistiche in acque sotterranee del Maghreb (Tunisia, Algeria, Marocco) e dell' Egitto. Natura Soc. ital. Sci. nat., Museo civ. Stor. nat. e Acquario civ. Milano, $72: 63-98$.

Petkovsi T. \& Meisch C. 1996. - Species of the genus Stenocypris Sars, 1889 from the rice-field of Macedonia (Crustacea, Ostracoda). Trav. sci. Mus. nat. hist. nat. Lux., 23 : 57-85.

Plénet S. 1995. - Freshwater Amphipods as biomonitors of metal pollution in surface and interstitial aquatic systems. Freshwat. Biol., 33 : 127-137. 
Plénet S. \& Gibert J. 1995. - Comparison of surface water/groundwater interface zones in fluvial and karstic systems. C. R. Acad. Sci. Paris, Sciences de la vie, 318 : 499-509.

Plénet S., Hugueny H. \& Gibert J. 1996. — Invertebrate community responses to physiological and chemical factors at the river/aquifer interaction zone. II. Downstream of the city of Lyon. Arch. Hydrobiol., $136: 65-88$.

Robert B. 1998. - Quelltypische Köcherfliegen (Insecta : Trichoptera) in Nordrhein-Westfalen (Deutschland) - Ein Überblick. In : Studies in crenobiology. The biology of springs and springbrooks, L. Botosaneanu( ed.), Backhuys Publisher, Leiden : 109-123.

Rodier J. 1996. - L'analyse de l'eau : eaux naturelles, eaux résiduaires, eau de mer. $8^{\mathrm{e}} \mathrm{Ed}$. Dunod. Paris : $365 \mathrm{p}$.
Turquin M.-J. \& Crague G. 1994. - Impact de la gestion des eaux usées sur la biocénose cavernicole, la zone noyée et la source du système karstique de Rappe (Neuville-sur-Ain, France). Bull. Soc. Linn. Lyon, $63:$ 337-348.

Valett H. M., Fisher S. G. \& Stanley E. H. 1990. - Physical and chemical characteristics of the hyporeic zone of a Sonoran Desert stream. J. N. Am. Benthol. Soc., 9 : 201-215.

Webb D.W., Wetzel M.J., Reed P.C., Philippe L.R. \& Young T.C. The macroinvertebrate biodiversity, water quality, and hydrogeology of ten karst springs in the Salem Plateau section of Illinois, USA. In : Studies in crenobiology. The biology of springs and springbrooks, L. Botosaneanu (ed.), Backhuys Publisher, Leiden : 39-48. 